\title{
Innovation and National State in the History of Economic Thought: Marx, Schumpeter and neo-Schumpeterians in retrospective
}

\author{
Pablo Benchimol ${ }^{1}$
}

Enviado: 14 de enero de 2019 / Aceptado: 08 de mayo de 2019

\begin{abstract}
Innovation is a fundamental concept in the history of economic thought. Indeed, Marx tried to find the conceptual thread that explained not only the law that governed the movement of innovations in the capitalist system, but also the development of the productive forces regardless of their historical epoch. Schumpeter represented a sudden fork in this theoretical path by rejecting those undertakings that intended to establish general universal laws. This turning point would pave the way for a neo-Schumpeterian evolutionary approach in which scholars sought to continue the legacy of their mentor in the descriptive deepening of the phenomenon and in the discussion of the role of the state within this framework. In the present article, we explore the transformation of the concept of innovation and the manner in which it has been connected with the notion of the national state by reconstructing the advances and setbacks in this process.
\end{abstract}

Keywords: Innovation, National State, History of Economic Thought, Marx, Schumpeterian and evolutionary approach.

JEL classification: B150, B41, O030

[es] Innovación y Estado Nacional en la Historia del pensamiento económico: Marx, Schumpeter y los neo-schumpeterianos en retrospectiva

Resumen: El concepto de innovación ha sido fundamental en el desarrollo de la historia del pensamiento económico. En este campo, Marx procuró explicar el movimiento de las innovaciones en el sistema capitalista y, de manera más general, el desarrollo de las fuerzas productivas independientemente de su época histórica. Schumpeter representó un súbito giro en este camino al rechazar aquel intento de establecer leyes universales de carácter general. Este punto de inflexión allanaría el camino para el posterior despliegue de un enfoque neo-schumpeteriano que aspiraba a continuar el legado del maestro a través de la profundización descriptiva del fenómeno innovador asociado al debate sobre el papel del Estado. En este marco, el presente artículo explora tal transformación del concepto de innovación, así como la forma en que, con sus avances y limitaciones, se ha conectado con la noción de Estado Nacional.

Palabras clave: Innovación, Estado Nacional, Historia del Pensamiento Económico, Marx, enfoque schumpeteriano y evolucionista.

Códigos JEL: B150, B41, O030

Sumario: 1. Introduction. 2. The concept of innovation in Marx and Schumpeter. 3. "Evolutionary economics" and the notion of State: chronological continuation, conceptual development?. 4. Power in Modern State and Civil Society: some suggestions to develop. 5. Concluding remarks. Bibliography

Cómo citar: Benchimol, P. (2019) Innovation and National State in the History of Economic Thought: Marx, Schumpeter and neo-Schumpeterians in retrospective, en Iberian Journal of the History of Economic Thought 6(2) (2019), 103-114.

pablobenchimol@gmail.com

Becario doctoral CONICET (Consejo Nacional de Investigaciones Científicas y Técnicas);

Docente de Historia del Pensamiento Económico UBA (Universidad de Buenos Aires) y UNLaM (Universidad Nacional de La Matanza); Investigador del CEPLAD (Centro de Estudios para la Planificación del Desarrollo), UBA, Buenos Aires, Argentina. 


\section{Introduction}

Innovation is a fundamental concept in the history of economic thought. Indeed, Marx tried to find the conceptual thread that explained not only the law that governed the movement of innovations in the capitalist system, but also the development of the productive forces regardless of their historical epoch. Schumpeter represented a sudden fork in this theoretical path by rejecting those undertakings that intended to establish general universal laws. This turning point would pave the way for a Schumpeterian evolutionary approach in which scholars sought to continue the legacy of their mentor in the descriptive deepening of the phenomenon and in the discussion of the role of the state within this framework.

In the present work, we intend to explore the transformation of the concept of innovation and the manner in which it has been connected with the notion of the national state. We aim to reconstruct the advances and setbacks in this process, as well as the necessary reinterpretation of the concepts of power and planning that permeate not only the world of "political relations", characteristic of the modern state (and its empirical incarnation: the national state), but also in the field of civil society, where "economic relations" between capital enterprises prevail.

The structure of this paper is as follows. In the second section, after the introduction, we address the way in which the concept of innovation was presented by Marx within the framework of his critique of political economy, as well as the discussions that this concept generated in relation to the metaphysical approach of general universal laws. On this basis, we also reconstruct the way in which Schumpeter took up and reacted to the Marxian approach of innovation and metaphysics. In the third section, we present some of the discussions developed within the evolutionary framework, as a continuation of the Schumpeterian approach, which focuses on the description of the innovative process and the conception of the national scope as the relevant sphere of analysis of these types of processes. In the fourth section, we discuss some of the theoretical clues that, we understand, can contribute to developing a more comprehensive conceptual analysis of innovation, not limited to the empirical approach. To conclude, some final comments are presented.
2. The concept of innovation in Marx and Schumpeter

\subsection{Innovation in Marx and "the general laws"}

The development of the concept of innovation is present in the principal authors of political economy. In Smith ([1776] 1976) it appears as one of the consequences of the division of labor, while Ricardo ([1817] 1973) sees innovation as one of the key elements of the capitalist system in helping avoid secular stagnation. However, it was Marx ([1867] 2015) who first placed the continuous process of technical transformations and, particularly, the development of innovations at the center of the system. In this regard, Sweezy, one of the most recognized Marxists, argues as follows:

Whereas in the classical theory, changes in productive methods are treated as dependent upon essentially fortuitous inventions and discoveries, in Marx's theory they become necessary conditions for the continued existence of capitalist production. (...). In the Communist Manifesto, Marx said: "The bourgeoisie cannot exist without constantly revolutionizing the instruments of production, and thereby the relations of production, and with them the whole relations of society." In Capital he rooted this insight in the soil of economic theory. In this way he discovered one of the most important of the 'laws of motion' of capitalism which it was the announced intention of Capital to explore. (Sweezy [1942] 1962, 93-94)

After discovering the source of surplus value in the unpaid hours that the worker deploys in the productive process, Marx investigates the ways in which the amount of surplus value can be increased. The first, called absolute surplus value, is produced through the extension of the working day. The limitations of this mechanism make it necessary to investigate a more powerful and relevant second option. This second form is called relative surplus value. Indeed, Marx explains that through the development of the productive forces the amount of labor needed to produce the wage goods decreases, which leads to a reduction in the value of the labor force. This implies, cateris paribus, an increase in the hours of surplus labor that the capitalist appropriates as surplus value. 
The concept of development in the productive forces is introduced as part of a necessary process in capitalist production: the mechanism by which capital creates and appropriates greater amounts of surplus value, in order to increase its own value. The growth of relative surplus value is carried out through two main elements: i) the development of science and ii) the centralization of capital (Marx [1867] 2015).

On this basis, Marx presents the different procedures through which relative surplus value is deployed considering the system as an aggregate. After chapters XI (co-operation) and XII (division of labour and manufacture) of volume I of Das Kapital, Marx presents in chapter XIII (machinery and modern industry) from which its main result is derived: science, understood as the form in which the capacity to organize the work process in the most powerful way is produced. This would be the fullest expression of the development of relative surplus value.

Modern industry rent the veil that concealed from men their own social process of production, (...). The principle which it pursued, of resolving each process into its constituent movements, without any regard to their possible execution by the hand of man, created the new modern science of technology. The varied, apparently unconnected, and petrified forms of the industrial processes now resolved themselves into so many conscious and systematic applications of natural science to the attainment of given useful effects. (Marx [1867] 2015, 318, italics added)

But from the point of view of individual capital, the objective of each will be to obtain an extraordinary profit. For Marx, this constitutes one of the bases of capitalist competition and also explains the incentive that individual capital has for introducing a technical novelty that gives it an advantage, at least temporarily, over its competitors, becoming the source of an extraordinary surplus value, again, at least for a while.

In exposing the different forms assumed by capitalist competition, Marx presents an additional element of importance to this framework. In effect, he shows how the centralization of capital allows the organization of increasing quotas of social work, understanding also that it "is the starting point for a more comprehensive organization of the collective work of many, for a wider development of their material motive forces" (Marx [1867] $2015,442)$. In this way, Marx explains how the productive forces also develop by enlarging the scale of centralized capitals.

However, the important issue here is the following: relative surplus value will only be "the capitalist form" of carrying out the development of the productive forces, a specific process that also has a generic dimension. Marx presents the main traces of this explanation in Das Kapital at the end of Volume I, in the closing of chapter XXIV "The historical tendency of capitalist accumulation". In this chapter, the generic moment of the development of the productive forces is clearly identified and it is not strictly limited to the specifically capitalist mechanism of relative surplus value but is broadened to previous historical stages and even projected to future ones.

Despite the discussions on this issue during the last century, both followers and detractors of Marx (Cohen [1978] 2001; Furet 1988) interpreted historical materialism as a new version of the philosophy of history; a philosophy, now materialist, of history, whose engine would be technical progress (Tarcus 2008).

Within this framework, the reconstruction of the dilemma that Schumpeter carries out helps us consider the advances and limitations of the Marxian approach. As we will see below, Schumpeter finds that the way in which the development of the productive forces operates to explain historical evolution is associated with metaphysical elements. Indeed, Schumpeter will examine the structure of analysis on which the general principles are founded: the unfolding of human history. On this basis, some fundamental questions will be posed regarding how these general principles are explained and where they come from.

\subsection{Innovation in Schumpeter's work as a transition to "evolutionary economics"}

Although the problem of innovation was, in general terms, minimized by the neoclassical doctrine, other authors began to consider the topic as a central issue of the discipline in order to understand the transformations and dynamics of modern capitalism. Schumpeter was one of the most recognized authors in this field and became one of the main exponents in the investigation of technological innovations out- 
side the Marxian doctrine (Sweezy 1943). He was even recognized as "the prophet of innovation" (McGraw 2007).

Schumpeter's main objective is to explain economic development. The key in this framework is precisely to focus on changes or transformations and then on the phenomena that appear because of them. However, it is necessary to specify the idea of "changes" to which Schumpeter refers in order to approach the notion of development. Indeed, "By 'development', therefore, we shall understand only such changes in economic life as are not forced upon it from without but arise by its own initiative, from within." (Schumpeter [1912] 1983, 37).

The internal (economic) changes that will define economic development will then be the "putting into practice of new combinations" of the elements necessary for the deployment of production. These new combinations will be strongly associated with the creation of new products and also with the creation of new production methods. In this framework, Schumpeter puts the problem of innovation at the center of the scene of his conceptual apparatus on economic development.

There have been various discussions among the Schumpeterian interpreters about the coherence of their work, due to the presumed changes it went through between its early and late phase with respect to the agent in charge of carrying out the innovations. Indeed, it has been postulated that Schumpeter lost initial faith in the entrepreneur and assigned that role to the large corporation (Michaelides and Kardasi, 2010; Becker and Knudsen, 2002). However, even taking into account these nuances, there is a general consensus about the central role of the concept of innovation for economic development (Andersen, 2009; Langlois, 2002).

The attempt to understand economic development as a process that presents "internal transformations" and not only adaptations to changes imposed from outside can find relevant antecedents. Schumpeter himself finds in Marx a reference in this field, while he recognizes that his approach covers only a part of the field studied by the Marxian approach:

This statement of the problem is more nearly parallel to that of Marx. For according to him there is an internal economic development and no mere adaptation of economic life to changing data. But my structure covers only a small part of his ground. (Schumpeter [1912] 1983, 45).
However, in order to fully understand Schumpeter's approach to economic development we must reconstruct a key notion which appears in his work. The notion of metaphysics. Indeed, Schumpeter does not ignore the relevance of metaphysical thinking and, particularly, the role it plays in the explanation of the "meaning" and "evolution" of history. In this regard, he is very critical of metaphysical thought as, according to his understanding, it seeks to account for the progress of different processes, such as history itself. In Theory of Economic Development, Schumpeter expresses discontent with this argumentative format that is strongly discredited in different fields of science, particularly in the economic field, where these ideas are labelled as "unscientific and extra-scientific mysticism". Thus, Schumpeter becomes a fervent anti-metaphysicist and his rejection of great generalizations is explicit: "many of us have lost patience" (Schumpeter [1912] 1983, 37). In this context, the methodological guideline proposed by Schumpeter is not free of problems and finds significant influences in different fields of philosophical thought, as in the positivism of Ernst Mach (Shionoya 1990; Hayek 1980). However, what we are interested in understanding here is how Schumpeter, considering his opposition to "hasty generalizations", broadens a horizon of analysis that will be deepened by continuators. Indeed, one of the main characteristics that the Schumpeterian approach bequeaths to its successors is the increasingly descriptive approach to the processes and sub-processes involved in the development of innovations.

\section{3. "Evolutionary economics" and the notion of State: chronological continuation, conceptual development?}

\subsection{Deepening the description of innovative processes}

One of the main concepts that Schumpeter leaves as a legacy to his successors is that of innovation as the center of the analysis of economic development. The way in which his work is continued has specific characteristics. This continuity is reflected in the fact that the research of its successors, evolutionary and neo-Schumpeterian authors, also has an important descriptive imprint of the phenomenon 
and, as we understand, avoiding as Schumpeter did the aspiration to achieve far-reaching transcendent general laws. This implies a deepening of the rejection of metaphysics first proposed by Schumpeter.

Indeed, the authors associated with neo-Schumpeterian and evolutionary ideas deepen the characterization of innovations, regarding the Schumpeterian heritage. In this context, they postulate that the innovative process, in general terms, has specific features. Johnson and Lundvall (1994) condense these characteristics into three major elements. First, innovation is cumulative; second, it involves the treatment of tacit and specific knowledge; third, the results that it may produce are very uncertain.

The first element is the cumulative nature of innovation. Certainly, even in cases of radical changes in productive techniques -which may seem to be something "absolutely new"the technical heritage accumulated in years of human history is very significant. In a contemporary setting, even laboratories or R\&D departments of large firms gather knowledge originated from outside the company and combine it with that generated within it (Dosi 1988). This conscious search for knowledge is not the only source of innovation but is complemented by a learning process.

The second element is linked to a very important topic in the development of the capacity to innovate: the learning process. Indeed, the learning process shows a strong tacit component, as in many cases the technique cannot be copied or transferred in a codified way (such as manuals, instructions or blueprints), but the experience in production is crucial. The evolutionary authors argue that this characteristic of learning describes the reason why the process of innovation is determined by its previous trajectory (path dependence). In this sense, the specific past history is projected into the evolution of future capabilities (Nelson \& Winter 1982; Dosi 1988). From this, it follows that any innovation system will also have a specific component in its innovative capacity.
To deal with the third component, we must consider that innovation, by definition, embodies a process of creating something new and hitherto unknown. It is obvious that, in a process with these characteristics, the management of high levels of uncertainty is the law, rather than the exception. Therefore, the treatment of the behavior that involves an action aimed at developing innovations is not free of problems. Indeed, in a process of this nature it is contradictory to speak of "rational choice" (Johnson \& Lundvall 1994). If the alternatives were known in advance, an innovation process would not be necessary, but if the agents do not know what to choose, it is impossible to define what a "rational" option is.

As can be seen from the previous points, the descriptive deepening of the innovative process (especially in the phase prior to its realization) and the search for "stylized facts" will be a constant in this doctrine and will constitute one of the main contributions of the evolutionary framework to economic thinking.

\subsection{The scope of the innovative process and the relevance of the national state as a unit of analysis}

Within the evolutionary analytical framework, the accent placed on public policies is fundamental. The state plays a key role in the innovation process, being one of the main responsible parties in defining the norms and standards that affect the pace and direction of innovations. From the National Innovation System (NIS) ${ }^{2}$ approach, it is the state which is the agent with the capacity to oversee, design and organize the implementation of a general technological policy ${ }^{3}$.

At this point, some important questions arise. To what extent does the scope of the innovation system have to be confined to $n a$ tional borders? Is this national approach conditioned by the advance of so-called globalization? In short, is the national scope enough to explain the processes of technological change or should it being understood in a broader context?

For simplicity, we consider the NIS approach here as a constitutive part of the evolutionary approach. The relation of identity and difference between the two is, however, a matter of discussion in the literature (López 1996).

This is a distinctive element with respect to some of the antecedents mentioned. Indeed, the national dimension is not particularly explored in Schumpeter when discussing the concept of innovation. In the case of Marx, the concept of national state is presented in other roles, such as the responsibility for the minting of a national currency and the regulation of working hours (chapters 3 and 8 of Das Kapital, respectively). However, it is not explicitly and systematically presented as a relevant agent in the framework of the development of innovations. 
A first response in defense of the national approach is given by Johnson and Lundvall (1994). Their argument in favor of the national approach aims to focus on the field in which the information is generated, as well as the scope where innovation policies are formulated. For these authors, the focus on national systems -rather than local, regional or transnationaldoes not derive from a merely theoretical understanding of innovation, but from considerations about economic history: national states have been important because they have allowed the creation of favorable social and economic environments for innovation processes. Furthermore, focusing on national systems reflects a pragmatic and political choice: most statistical information is generated in the country and economic policies on innovation were then formulated and are still formulated to a considerable degree, by national dependencies (Johnson \& Lundvall 1994). Another example of this kind of argument is given is the following:

Our view on the issue has always been pragmatic and reflects that we see the policy dimension of the concept as important. As long as nation states exist as political entities with their own agendas related to innovation, it is useful to work with national systems as analytical objects. (Lundvall et al. 2001, 8, italics added)

These arguments, with a more pragmatic than theoretical tone, are complemented by a second type of reason that follows a historical-descriptive nature. It is also argued that the different historical and cultural trajectories will be reflected in national idiosyncrasies regarding: a) internal organization of the firms; b) interfirm relations; c) role of the public sector; d) institutional framework of the financial sector; e) organization and intensity of $R \& D$ activities; f) the national education and training system. The "ideologies" and political systems of each country will also be influential factors in this regard (Johnson \& Lundvall 1994; Lundvall 1992).

We can distinguish a third argument, perhaps the most interesting to be developed, associated with a more detailed description of the innovation process and its consequences. Lundvall (1992) asserts that national systems still play an important role in supporting and directing innovation and learning processes. Considering the inherent uncertainty in the innovation process and the relevance of learning within that frame- work, the author argues that particularly complex communication is required between the parties involved, especially when the knowledge exchanged is tacit and difficult to codify. In this context, when the parties involved are linked in the same national environment -sharing their norms and their cultural interpretation system-, interactive learning and innovation will be easier to develop. In his own words:

(...) we believe that national systems still play an important role in supporting and directing processes of innovation and learning. The uncertainties involved in innovation and the importance of learning imply that the process calls for a complex communication between the parties involved. This will especially be the case when the knowledge exchanged is tacit and difficult to codify. When the parties involved originate in the same national environment - sharing its norms and culturally based system of interpretation-interactive learning and innovation will be easier to develop. (Lundvall 1992, 4, italics added)

Following the previous argument, Johnson and Lundvall (1994) find additional elements to look at the question in a national context. Indeed, the interactive nature of the innovation process opens up a new horizon of connections to the cultural and social environment, which often changes radically between nations. Here we can find different nuances, depending on the analyzed sectors. An extreme case would be the advances developed in so-called "basic science", which can be easily transmitted internationally by effective telecommunication services. On the other side of the scale, we have the cases of complex processes whose technical progress requires practical learning that demands tacit and specific knowledge (Johnson \& Lundvall 1994, 699).

Nelson (1993), in opposition to these arguments, has serious doubts about the relevance of maintaining a national-centered approach. The question he asks is: "what remains national about innovation systems?" There obviously are some difficulties with the concept of a "national innovation system":

One cannot draw a line neatly around those aspects of a nation's institutional structure that are concerned predominantly with innovation in a narrow sense excluding everything else, and still tell a coherent story about innovation in a broad sense. (Nelson 1993, 517-518, italics added) 
Regarding the aforementioned impossibility, Nelson explains his reasons when answering the mother of all questions: "what remains national about innovation systems?" The main argument points out that the differences between firms based on their histories, policies and cultures will be progressively less important. This will be the result of processes of cultural homogenization, the greater attention of managers towards what happens in other countries, the alliances between firms from different countries and the extension of the process of internationalization of productive capital. Although many firms will continue to have "national" bases, their relative weight would tend to decrease. In his own words:

\section{(...) we recognized that borders around nations} are porous, and increasingly so. Indeed, one of the questions that motivated this study was whether the concept of national innovation systems made sense anymore. I suspect that many of us come out on this as follows. (...) It is safe to say that there will be increasing internationalization of these aspects of technology that are reasonably well understood scientifically. Efforts on the part of nations, and firms, to keep new understandings won in research and development privy increasingly will be futile. Among firms with the requisite scientific and technical people, the competitive edge will depend on the details of design, production process, firm strategy and organization, upstream-downstream connections, and so on. (...) It is also safe to say that differences across firms stamped into them by national policies, histories, and cultures will diminish in importance. Partly that will be because the world is becoming much more unified culturally, for better or for worse. Partly it will be because firm managers and scholars of management increasingly are paying attention to how firms in other countries are organized and managed. And cross-country interfirm connections are likely to grow in importance. (...) Thus, increasingly, the attempts of national governments to define and support a national industry will be frustrated because of internationalization. (Nelson 1993, 518-519 italics added)

Nelson and Wright (1992) introduce a "historical dimension" to the discussion. They ar- gue that the notion of "national technology" is a useful and defensible analytical abstraction, which was appropriate throughout much of modern history. However, during recent decades its importance (and usefulness) has decreased.

Indeed, the authors say that, before the end of the Second World War, there were sufficient arguments to carry out a national approach. In general terms, these reasons are like those explained by the defenders of the national approach and are associated with a detailed description of technological progress. Nelson and Wright (1992) emphasize three elements. First, to get technologies under control and operating well generally required a lot of learning-by-doing on the part of many interacting people, from engineers to managers. Second, to a considerable extent technical advance in these fields was local and incremental, building from and improving on prevailing practices. So, the knowledge useful for advancing technology included, prominently, experience with the existing technology, to be aware of its strengths and weaknesses, and to know how it actually worked. Third, sustained technological advance was not the result of one person or firm pushing things ahead, but involved many interacting people and firms (Nelson \& Wright 1992).

Ultimately, technological progress was seen eminently as a network phenomenon. A striking historical feature of these networks of cumulative technological learning is that down to recent times their scope has been largely defined by national borders. Nelson and Wright ask: why should this have been so? First, for reasons of geographical proximity: the networks involved inventors and tinkerers living in the same general area and having intimate contact with each other's inventions. Second, "the extent that technological communications networks follow in the tracks of previously established linguistic and cultural communities, it would be entirely natural for technologies to have something of a national character" (Nelson \& Wright 1992, 1936).

Nevertheless, the internationalization of trade and production ${ }^{4}$, as part of the post-war development, has been considered an important process in the erosion of hard national borders as barriers obstructing or channeling access to technology.

4 This process is analyzed by different authors. The main discussions are presented in the so-called new international division of labor (NIDL) (Fröbel et al. 1980) and global value chains (GVC) (Gereffi 2001); where the pertinence of delimiting the analysis of the NIS to a national scope is still being questioned. 
Nelson and Wright (1992) mention some relevant empirical transformations to explain this process. On the one hand, and in contrast to an earlier era, a larger proportion of the generic knowledge relevant to a technology now is written down, published in journals, discussed at national and international meetings, taught in schools of engineering and "applied science". On the other hand, and regarding the internationalization process, employees often move across national borders, within a firm or between firms. These are truly international networks, involving highly trained scientists and engineers, employed in universities and in industry, undertaking significant R\&D efforts. The result of these transformations, according to the authors, is as follows: the technologies emerging from such networks no longer have geographic roots, because horizons have become global.

So, taking into account that the networks of technological development and communication have become more oriented to professional peer-group communities, which have themselves become increasingly international, technology has become more accessible to companies that make the requisite investments in research and development, regardless of their nationality. Increasingly, such investments have been made by firms based in other countries. These developments are associated with the fact that large industrial firms are increasingly transnational. Where national industries become tradition-bound and fall behind, international convergence is still advanced by the migration of capital, management, and personnel across international borders. The net result of these developments is a world in which national borders and citizenship mean significantly less technologically than they used to (Nelson \& Wright 1992).

Within this framework, considering that technology does not remain within national borders, it will be observed that national technological policies no longer have the same impact:

Indeed, the last decade has seen a sharp increase in what has been called "techno-nationalism," policies launched by governments with the objective of giving their national firms a particular edge in an area of technology. Our argument is that these policies do not work very well any more. It is increasingly difficult to create new technology that will stay contained within na- tional borders for very long in a world where technological sophistication is widespread and firms of many nationalities are ready to make the investment needed to exploit new generic technology. A closely related observation is that a well-educated labor force, with a strong cadre of university trained engineers and scientists at the top, is now a requirement for membership in the "convergence club". This is not to denigrate the continued importance of hands-on learning by doing and using, but in modern technologies this is not sufficient. (Nelson \& Wright 1992, 1961 , italics added)

Regarding the recapitulation on the arguments for and against the national approach, we can find some hints that, we understand, may be relevant to be developed. The emphasis placed on the national level (in those authors who consider it a relevant approach) is closely linked to the characterization and descriptive deepening of the innovation process, which we mentioned in the previous section (3.1). The relevance assigned by the evolutionary literature to tacit and specific knowledge in innovative processes is a fundamental aspect when it comes to justifying the national approach associated with the "immobility" of parts of the innovation process. However, this perspective based on the description of innovative processes is also present among those who doubt the relevance of the national approach, in a context of "internationalization of production" (and innovations, as an inseparable part of that). In short, both defenders and detractors share the empirical and casuistic study as a common basis for the analysis of the scope of the problem. Both relevant views meet again: the descriptive deepening and the national approach are only two sides of the same coin.

Finally, despite the progress of the descriptive deepening shared by both approaches, there are some concepts that are not sufficiently articulated. Indeed, despite the debate, neither defenders nor opponents of the national approach have developed a notion of the national state sufficiently integrated into a conceptual framework. Instead, this notion is postulated as an external entity that "intervenes" to a greater or lesser extent in the field of "the economy". In more general terms, the concept we will have to broaden is that of power. In the next section, some hints on this concept are developed. 


\section{Power in Modern State and Civil Society: some suggestions to develop}

As we have seen in the previous section, the neo-Schumpeterian and evolutionary approach presents a useful description of the innovative process, discusses the scope of this process in national terms and, for this, incorporates the role of the national state. In working with the notion of the national state, the notion of power embodied by that institution is presupposed. However, the concept of power is not fully integrated theoretically.

In general terms, we find in the neoclassical doctrine, as well as in the doctrine of the GVC, a limited presentation of the notion of (market) power. This notion: i) tends to be reduced to a conjunctural expression; and ii) is not explained, but assumed as a given element, which has no specific origin or transformation law.

Indeed, theoretically power relations are not fully presented within the framework of "the economy" or civil society. Instead, power appears in the opposite field and, therefore, "outside" the economic domain: it is the concept of modern state and its empirical incarnation, the national state.

Marx encountered at this point precisely political economy. His first subject matter was not the economy, but the state. In one of his "earliest" works, "Critique of Hegel's Philosophy of Right", Marx's immediate problem was not capital, but the modern state. However, his critique of Hegel's work in particular and his critique of the theory of the state in general, remained unfinished; it was not possible to say anything more about the state without penetrating the nature, the anatomy, of civil society. The development of the science of civil society would be the only option to understand the foundation of the modern state. His intention would turn, therefore, to carry out the critique of political economy (Romero 2014). This transition would be explicit and immortalized by Marx himself in the preface of $A$ Contribution to the Critique Political Economy:

The first work which I undertook to dispel the doubts assailing me was a critical re-examination of the Hegelian philosophy of law; the introduction to this work being published in the Deutsch-Franzosische Jahrbucher issued in Paris in 1844. My inquiry led me to the conclusion that neither legal relations nor political forms could be comprehended whether by themselves or on the basis of a so-called general development of the human mind, but that on the contrary they originate in the material conditions of life, the totality of which Hegel, following the example of English and French thinkers of the eighteenth century, embraces within the term "civil society"; that the anatomy of this civil society, however has to be sought in political economy. (Marx [1859] 1993, 3, italics added)

On this journey, Marx would articulate and overcome previous economic thought through, mainly, his contribution in the field of the concept of value or, more precisely, in the development of the form of value.

Indeed, through the concept of the form of value, Marx managed to explain the genesis of money starting from the simple exchange of commodities; that means, internally, without appealing to external elements of the commodity relation itself. From this new concept, the prevailing rules in economic theory were broken: the genesis of money, the necessary product of the commodity relation, showed how power relations return to a land they had abandoned. Money was the general form of value; it was a commodity in which the world of the remaining commodities expressed its value, which gave it a power over them, by becoming a directly exchangeable commodity. That power was transferred to its possessor, introducing a relation of inequality, of power, within the relation of equals that the concept of civil society supposed. In this context, power was generated from the very bowels of civil society, which until then had been the area of equality amongst the parties.

In this context, we find some clues to integrate the notion of power-and through it the notion of state-, into a conceptual structure that contains them within the framework of civil society. In the technological capital approach, Levín (1997) follows the rigorous explanation of the concept of form of value proposed by Marx, to discover that power springs from the civil society itself. Levín finds in the explanation of the form of value and in the commodity differentiation between simple commodity and money, the first conceptual steps to explain capital differentiation.

The concept of capital differentiation shows -again- that economic relations are not relations between equals, but the expression 
of power relations inside civil society. The scope of capital enterprises is a hierarchical and heterogeneous environment based on the capacity of some capital enterprises to systematically appropriate the capacity to innovate and exclude the rest from reaching that capacity (Levín 1977). Levín calls the former, enhanced capital enterprises, and simple capital enterprises, the latter.

The national state -as an empirical incarnation of the modern state- no longer represents the sphere of power, opposed to civil society, as an expression of equality. This is because power is immanent in the development of civil society, determining the relation between capital enterprises. In this context, the state can be understood as a power between powers. Moreover, a hierarchical structure of national states can also be conceived, considering different relative powers.

\section{Concluding remarks}

Throughout this paper, we have reconstructed the way in which the concept of innovation features in Marx's work and how it was embedded in a broader field: the development of productive forces, regardless of their historical form. This extension led us to address the discussions that took place around the so-called Marxian theory of history and, with it, the presence of problematic metaphysical elements.

Schumpeter also aimed to find in the innovative process the basis for understanding the economic development of the system. Despite that, he would become one of the greatest detractors of "Marxian metaphysics".

Regardless of the success and stumbling blocks of his own strategy, the fact is that the Schumpeterian and evolutionary continuators, even with all their nuances, would find a way to continue the work of their mentor. They would do this in two ways: i) deepening the description and characterization of the innovative process (and its different sub-processes) and, ii) discussing the national scope as a relevant sphere to account for the concept of innovation, as well as the role of the national state within this framework.
These two fields are closely linked. Indeed, we have found that both defenders and critics in the discussion regarding the relevance of the national sphere, base their arguments mainly on the enumeration of empirical elements in the innovation process.

On the one hand, one of the arguments put forward by the "defenders" of the national approach was linked to the description of a fragment of the innovative process: the learning process. Given the relevance of learning, they argue that when the parties involved in that process are at the same national level, and therefore share cultural norms and systems of interpretation, interactive learning and innovation will be easier to develop. In that context, the national approach would make sense. On the other hand, authors who criticize the "national" approach, although they accept the importance of the learning sub-process as a part of the development of innovations, understand that the idea of "national technology" is no longer as relevant as it was before the Second World War. The post-war internationalization of production has homogenized the specific differences between histories and cultures, thereby reducing the relevance of the nation as a specific scope of analysis for the development of innovations.

However, this important descriptive contribution has not found a concept of the national state sufficiently integrated into the proposed theoretical body. It is postulated that this external entity "intervenes" in one way or another in the field of "the economy" without having fully investigated the concept of power.

Within this framework, we make some suggestions to pursue this imperative integration, following the conceptual development that maintains consistency with commodity differentiation and capital differentiation. On this basis, we think it will be possible to shed light not only on the hierarchical structure of capitals grounded on the concept of innovation, but also on the hierarchical structure of national states with which they are linked. It is a fundamental task, which should be undertaken in order to bring economic science upto-date. 


\section{Bibliography}

Andersen, Esben. 2009. Schumpeter's Evolutionary Economics. A Theoretical, Historical and Statistical Analysis of the Engine of Capitalism. Anthem Press, London.

Becker, Markus and Knudsen, Thorbjørn. 2002. Schumpeter 1911: Farsighted Visions on Economic Development, The American Journal of Economics and Sociology, 61 (2), 387-403.

Cohen, Gerald. [1978] 2001. Karl Marx's theory of history. A defence. Princeton: Princeton University Press.

Dosi, Giovanni. 1988. Sources, Procedures and Microeconomic Effects of Innovation. Journal of Economic Literature, 26 (3), 1120-1171.

Freeman, Chris and Soete, Luc. 1997. The Economics of Industrial Innovation. MIT Press.

Fröbel, Folker; Heinrichs, Jürgen and Kreye, Otto. 1980. The new international division of labour: structural unemployment in industrialized countries and industrialization in developing countries. Cambridge: Cambridge University Press.

Furet, François. 1988. Marx and the French Revolution. Chicago: The University of Chicago Press.

Gereffi, Gary. 2001. Las cadenas productivas como marco analítico para la globalización. Problemas del Desarrollo, 32 (125), 9-37.

Hayek, Friedrich. 1980. Prólogo a Methodological Individualism de J.A. Schumpeter. Bruselas: Institutum Europaeum.

Johnson, Björn and Lundvall, Bengt-Åke. 1994. Sistemas Nacionales de Innovación y Aprendizaje Institucional. Comercio Exterior, 44 (8), 695-704.

Langlois, Richard. 2002. Schumpeter and the Obsolescence of the Entrepreneur, Working Paper 2002-19, University of Connecticut.

Levín, Pablo. 1997. El capital tecnológico. Buenos Aires: Ed. Catálogos.

Levín, Pablo. 1977. Circuitos de innovación. Revista Interamericana de Planificación, XX (44).

López, Andrés. 1996. Las ideas evolucionistas en economía: una visión de conjunto. Revista Buenos Aires Pensamiento Económico, № 1, 93-154.

Lundvall, Bengt-Åke. [1992] 2010. National Systems of Innovation. Toward a theory of innovation and interactive learning. London: Anthem Press.

Lundvall, Bengt-Åke; Johnson, Björn; Andersen, Esben and Dalum, Bent. 2001. National systems of production, innovation and competence building. Department of Business Studies, Aalborg University.

Marx, Karl. [1859] 1993. A Contribution to the Critique of Political Economy. Moscow: Progress Publishers.

Marx, Karl. [1867] 2015. Capital. A critique of Political Economy. Moscow: Progress Publishers.

McCraw, Thomas. 2007. Prophet of innovation. Joseph Schumpeter and Creative Destruction. Cambridge: The Belknap Press of Harvard University Press.

Michaelides, Panayotis and Kardasi, Ourania. 2010. Schumpeter's theory of leadership: a brief sketch. The Journal of Philosophical Economics, III:2, 122-133.

Nelson, Richard. 1993. National innovations systems. A comparative analysis. London: Oxford University Press.

Nelson, Richard and Winter, Sidney. 1982. An evolutionary theory of economic change. Cambridge-Harvard, University Press.

Nelson, Richard and Wright, Gavin. 1992. The Rise and Fall of American Technological Leadership: The Postwar Era in Historical Perspective. Journal of Economic Literature, 30 (4), 1931-1964.

Ricardo, David. [1817] 1973. Principles of Political economy and Taxation. New York: Dutton.

Romero, Verónica. 2014. En busca de los fundamentos económicos de la teoría del Estado moderno. Apuntes para el Metaplán, Buenos Aires: CEPLAD, Instituto de Investigaciones Económicas, FCE-UBA.

Schumpeter, Joseph. [1912] 1983. Theory of Economic Development. New Brunswick: Transaction Publishers.

Schumpeter, Joseph. [1954] 2006. History of Economic Analysis. London: Routledge's Collection.

Shionoya, Yuichi. 1990. Instrumentalism in Schumpeter's economic methodology. History of Political Economy, 22 (2), Duke: Duke University Press.

Smith, Adam. [1776] 1976. An Inquiry into the Nature and Causes of the Wealth of Nations. Indianapolis: Liberty Classics.

Sweezy, Paul. [1942] 1962. The theory of capitalist development. London: Dobson Books. 
Sweezy, Paul. 1943. Professor Schumpeter's Theory of Innovation. The Review of Economics and Statistics, 25 (1), 93-96.

Tarcus, Horacio. 2008. ¿Es el marxismo una filosofía de la historia? Marx, la teoría del progreso y la 'cuestión rusa'. Andamios, Revista de investigación social, 4, (8) 7-32, México D.F.: Universidad Autónoma de la Ciudad de México. 